Open Access

\title{
Review of "the goddess pose: the audacious life of indra Devi" by Michelle Goldberg
}

\author{
Rebecca Polack
}

Correspondence: rebecca@ rebeccapolack.com

708 Ninth Avenue, San Francisco, California 94118, USA

\section{Book details}

The Goddess Pose: The Audacious Life of Indra Devi, the Woman Who Helped Bring Yoga to the West. By Michelle Goldberg. New York: Alfred A. Knopf, 2015. 336 pages. ISBN-10: 0307593517; ISBN-13: 978-0307593511.

Keywords: Indra devi, Modern yoga, Yoga

\section{Main text}

In The Goddess Pose, journalist Michelle Goldberg moves through the weft and warp of Indra Devi's "audaciously modern, sometimes inspiring, and sometimes maddeningly irresponsible" life (9), weaving together the strands of major socio-political events of the twentieth century with Devi's own personal circumstances. To be sure, Devi was a tour de force in almost every aspect of her life, and with the proliferation of both scholarly and popular books on the historical trajectory of modern yoga, it is especially refreshing to read about one woman's major impact on yoga in modernity.

Yet, even as Goldberg chases Devi back and forth over various continents to "understand where the yoga as we practice it in the West came from" (8), this book is less about the progress of yoga in modernity than Devi's many metamorphoses throughout her life-a Russian aristocrat-turned-actress and cabaret performer, a diplomat's wife during WWII, a friend to many of India's foremost freedom fighters including Jawaharlal Nehru, a yoga teacher to the fabulous and famous in Hollywood in the 1950s, and a spiritual advisor to Panama's second in command during the Noriega years, prior to settling in Argentina in her later years.

Her preoccupation with the mystic East drew the young intrepid Devi to the Theosophical Society's young messiah, J. Krishnamurti and later to her studies in the 1930s with eminent modern yogis of India, Swami Kuvalayananda and Sri T. Krishnamacharya, before ultimately becoming a devotee of the controversial Satya Sai Baba. It was following Krishnamacharya's bidding to teach yoga to Westerners that Devi first taught to fellow expatriates in Shanghai during World War II.

Undoubtedly Goldberg has done extensive research on Eugenia Vassilievna Peterson, the spirited woman who would become Indra Devi, yet The Goddess Pose is far from a scholarly treatise. Goldberg frequently veers off the main narrative into digressive

(c) 2015 Polack. Open Access This article is distributed under the terms of the Creative Commons Attribution 4.0 International License (http://creativecommons.org/licenses/by/4.0/), which permits unrestricted use, distribution, and reproduction in any medium, provided you give appropriate credit to the original author(s) and the source, provide a link to the Creative Commons license, and indicate if changes were made. 
expositions of historical people, places, and events with less success. Scholars and serious readers of modern yoga will recognize many of these vignettes as simplified reiterations of others writing in the field-such as early Western enthusiasm for Eastern esotericism and occult practices, Theosophy's modernizing impact on the yoga tradition, and Thoreau's oft-quoted, "to some extent, and at rare intervals, even I am a yogin" (98).

At the same time, Goldberg is frustratingly inconsistent with her citations, leaving the reader wondering at intervals where she gathered her information. In one example, Goldberg states that the yogi-scientist, Kuvalayananda, "combined asanas with calisthenics and moves that were traditionally part of the training program for Indian wrestlers-dands, or push-ups, and surya namaskars, a flowing series of lunges that today form an essential part of modern hatha yoga classes" (109). As someone who has written extensively on Kuvalayananda, I was curious to know Goldberg's source, but none was mentioned.

Despite the shortcomings of The Goddess Pose, Goldberg weaves an interesting, albeit casual, narrative of Devi's complicated, and often reckless, life. Audiences with little knowledge of this irrepressible woman-as well as the history of modern yoga-will be entertained. Yet, I for one would have preferred to see the tapestry of Devi's tale woven in the hands of a more knowledgeable and skillful biographer.

Competing interests

The author of this review declares that she has no competing interests.

Author's information

Rebecca Polack holds a Doctorate in Philosophy and Religion at the California Institute of Integral Studies (2014) with a concentrate in Yoga Studies. As an independent scholar, she teaches, writes and speaks on the History of Yoga and on the Modernization of the Yoga Tradition.

Submit your manuscript to a SpringerOpen ${ }^{\circ}$ journal and benefit from:

- Convenient online submission

- Rigorous peer review

- Immediate publication on acceptance

- Open access: articles freely available online

- High visibility within the field

- Retaining the copyright to your article

Submit your next manuscript at $>$ springeropen.com 